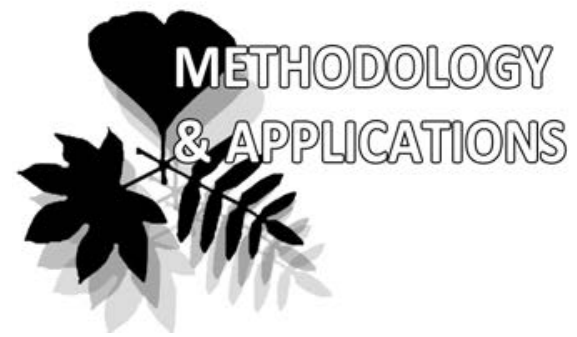

\title{
BIOKEYS software: an introduction for dichotomous keys use
}

\author{
Nguyen Van Sinh
}

Nguyen Van Sinh

e-mail: vansinh.nguyen@iebr.vast.vn

Institute of Ecology and Biological Resources, Vietnam Academy of Science and Technology, Hanoi, Vietnam

* corresponding author

Manuscript received: 12.05 .2019

Review completed: 18.06.2019

Accepted for publication: 26.06.2019

Published online: 01.07.2019

\begin{abstract}
A B S T R A C T
The paper is an introduction how to work with dichotomous keys in the BIOKEYS software (http://accountvienst.readyhosting.com/index.asp?prgID=1), including creating of dichotomous data, creating dichotomous key from dichotomous data, specimen identification by using dichotomous keys and illustration of the identification result with data from integrated database. This way of creating dichotomous data with successive creating dichotomous key in BIOKEYS software allows choosing the best version of dichotomous key both in evolutionary and phylogenetic meanings. Because $\mathrm{E}_{\text {dicho }}$ index allows to quantitatively evaluate performance of a dichotomous key based on the evenness of the number of steps to identification of all taxa, its calculation has been integrated in BIOKEYS software. K e y w o r d s : software, dichotomous key, BIOKEYS, taxonomy
\end{abstract}

\section{P E 3 Ю M E}

Нгуен Ван Шинь. Программа BIOKEYS: введение в использование Аихотомических кмючей. Эта статья представ яет собой введение в работу с Аихотомическими кАючами в программе BIOKEYS (http://accountvienst. readyhosting.com/index.asp?PrgID=1), и включает в себя создание Аихотомических данных, создание Аихотомического кАюча из этих Аанных, идентификацию образца с использованием построенных кАючей и илАюстрацию результата илентификации с Аанными из базы данных. Описанный способ создания Аихотомических Аанных с последовательным созданием Аихотомического кАюча в программе BIOKEYS позволяет выбрать Аучшую версию Аихотомического кАюча, отражающего как эволюционный, так и филогенетический смысл. Поскольку индекс $\mathrm{E}_{\text {dicho }}$ позволяет количественно оценить эффективность созАанного Аихотомического кАюча на основе равномерности количества шагов Аля идентификации всех таксонов, его расчет был интегрирован в программное обеспечение BIOKEYS.

КАючевые слова: программа, Аихотомический ключ, BIOKEYS, таксономия
The most easy and common way to identify the organism from unusual flora or fauna is the keying out using dichotomous keys - the basic element of various taxonomic monographs and manuals. However, before use the key should be created and then verified by practical use. The wide introduce of online papers and other electronic resources arises the problem of compilation online available keys to identification of various groups of animals, plants and fungi. This problem was in the focus of our studies for the last several years. Before (Nguyen 2015) we started the creation of special software and described how to use it for polyclave keys. The main goal of the present paper is to discuss how to create and use dichotomous keys and how to assess the performance of the created key.

The dichotomous keys consist of a series of paired characters (thesis and antithesis). Using the dichotomous keys always begins with the first pair of characters and selecting the character that best fits the specimen. This will direct the user to another pair of characters. This single access type of identification has defined disadvantage as the specimen can lack the character of the first pair of characters. The polyclave (multi-access) keys allow the user to enter the key at any point and the user can choose the most obvious and important characters of the specimen to identify. However, the dichotomous keys are still the most popular method of biological taxa identification.

BIOKEYS is an integrated system for working with database and identification keys, both polyclave and dichotomous. The taxonomists can use this software for creating keys and then students can use this software to identify the object using available keys.

\section{MATERIAL AND METHODS}

BIOKEYS software was created with using Embarcadero Delphi 10.1 Berlin Professional. The installation package of BIOKEYS is available on the homepage of the Institute of Ecology and Biological Resources (http://accountvienst. readyhosting.com/index.asp?prgID=1). BIOKEYS has 6 own file formats ("*.bkd" for the database file, "*.bki" for the polyclave key file, "*.bkc" for the coded polyclave key file, "*.bks" for the text file, "*.bk0" for the dichotomous data file, and "*.bkt" for the dichotomous key file). To create 
the user interface in BIOKEYS the visual component library (VCL) of Delphi was used. The user interface of BIOKEYS allowing working with dichotomous keys includes: 1) dialog box for creating dichotomous data; 2) dialog box for creating dichotomous key from dichotomous data; 3) dialog box for identification by using dichotomous key. Besides, $\mathrm{E}_{\text {dicho }}$, an index for evaluating performance of dichotomous keys, was developed (Nguyen et al. 2017). The idea of the index is that, as a key is intended for identification of each of the taxa in the group, the key will achieve the highest performance when the mean number of steps to their identification is minimal. The index therefore has Pielou's evenness index as a prototype (Pielou 1966) and is ranging between 0 and 1 $\left(0<\mathrm{E}_{\text {dicho }} \leq 1\right)$ and has following formula:

$$
\mathrm{E}_{\text {dicho }}=-\sum_{i=1}^{S}\left(p_{i} \ln p_{i}\right) / \ln S
$$

where: $S$ is the number of taxon in the group; $p_{i}$ is the proportion of the number of steps for identification of the $i$-taxon to the total number of steps needed to identify all the taxa of the group.

In BIOKEYS a dialog box is also provided for calculating $\mathrm{E}_{\text {dicho }}$ index. For opening this dialog box there is a submenu under the menu "Working with dichotomous key". BIOKEYS is bilingual software, switching language from Vietnamese to English (and vice versa) by clicking the second button of the toolbar of the main window.

\section{HOW TO WORK WITH BIOKEYS Dichotomous data in BIOKEYS}

Dichotomous data is a set of pairs of dichotomous characters with their lists of the taxa. Thus, each pair of dichotomous characters has two lists of taxa, a list consists of taxa that all have thesis character and the other list consists of taxa that all have antithesis character. Two lists of taxa of a pair of dichotomous characters can together consist as much as all the taxa of the taxonomic group that must be classified, or as little as only two taxa. The dialog box for creating dichotomous data in BIOKEYS is presented in the Figure 1. The larger set of dichotomous character pairs therefore provides the more chances to create reliable dichotomous key.
To enter the dichotomous data into BIOKEYS, at first the list of all the taxa should be created. For this purpose the name of each taxon will be typed into the edit field next to the label 'Adding taxa' with clicking mouse on it when the name of taxon is completed. After the list of all the taxa is created, the pairs of dichotomous characters with their list of taxa will be entered one after another, where the taxa for these lists are chosen from the list of all taxa. Each time when the two dichotomous characters of a pair were typed and their lists of taxa are completed, clicking on the button "Updating character" will enter the character pair. The dichotomous data can and should be stored in a file (with the extension of ".bk0") for later use. It is better to save the file immediately after entering the first pair of dichotomous characters with the corresponding lists of taxa, especially while working with desktop computer.

The published dichotomous keys can be used to create digital dichotomous key in BIOKEYS for subsequent identification of the name online when the access to the hard publication copy is difficult. The key for identification of hornwort genera of Columbia (Gradstein 2018) has been used here as an example of creating dichotomous data and dichotomous key, and of using dichotomous key (Fig. 1).

\section{Creating dichotomous key from dichotomous data in BIOKEYS}

The dichotomous key can be created in BIOKEYS from a file of dichotomous data by using the dialog box for creating dichotomous key (Fig. 2). In this dialog box when we open a dichotomous data file, BIOKEYS will create the list of all taxa and put it in the under the label "Taxa of selected group". This is the initial list of taxa to be classified, it is numbered zero and this number is added to the drop-down list under label "Choose taxon group to classify". Then BIOKEYS will search for all pairs of dichotomous characters, which have lists of taxa with total taxa amount equal to the taxa amount of all taxa list. These pairs of dichotomous characters will be numbered and the number of such pairs of dichotomous characters will be displayed in the up-down list after the button "Usable pairs of dichotomous characters".

The Figure 2 shows that, in our example, the dichotomous data has totally 7 taxa and there is one pair of dichotomous

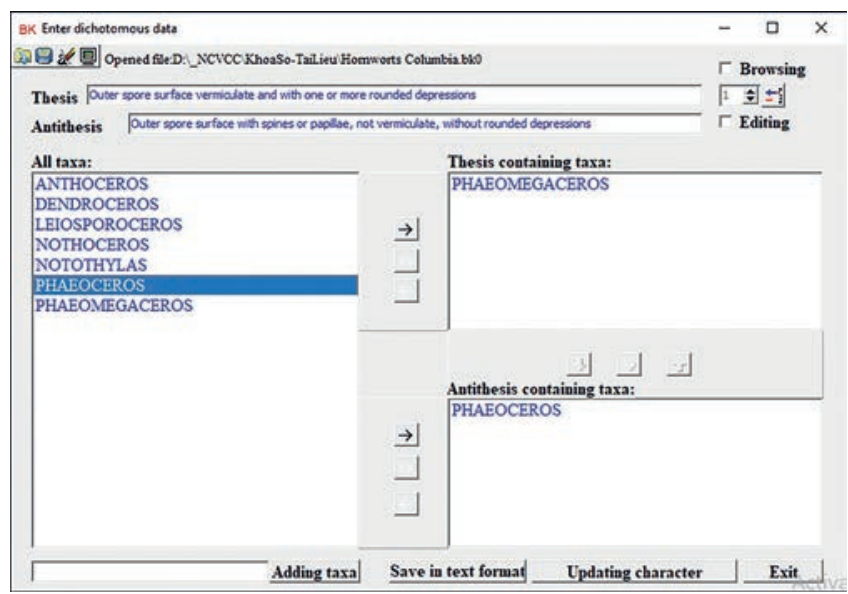

Figure 1 Dialog box for creating dichotomous data

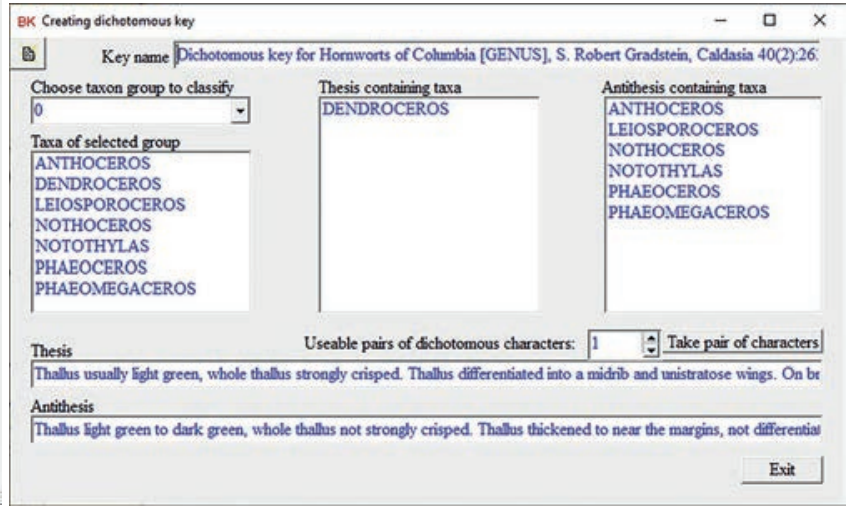

Figure 2 Dialog box for creating dichotomous key 
characters with total taxa amount of 7 . Because there is in this case only one usable pair of dichotomous characters, we have to take it for the classification by clicking on the button "Take pair of characters". But if there is more than one usable pair of dichotomous characters, we can use up-down button to choose a pair. If classification of a group of taxa creates new groups of more than one taxon, these new groups will be numbered and their numbers will be added to the drop-down list under label "Choose taxon group to classify".

Each step of the process of creating of dichotomous key in BIOKEYS includes choosing the group of taxa to be classified and clicking on the button "Take pair of characters" to choose the pair of dichotomous characters for classification of the chosen group of taxa. To choose the group of taxa to be classified we choose one number in the drop-down list under the label "Choose taxon group to classify". The process of creating dichotomous key will be finished when there no more unclassified groups of two or more taxa. BIOKEYS will then announce in a message box "Classification finished!" and let the user save the created dichotomous key in a file of ".bkt" format for later use in specimen identification with BIOKEYS, and in a text file of ".bks" format. BIOKEYS will also display the created dichotomous key in a child window (Fig. 3).

\section{Identification of specimen using dichotomous key in BIOKEYS}

The identification of specimen using dichotomous key in BIOKEYS is conducted in the dialog box "Identifying with dichotomous key" (Fig. 4). Once the dichotomous key is loaded, the character of each pair of dichotomous characters (thesis or antithesis) that matched with the specimen will be chosen by clicking on the corresponding option button. The option button will be selected and the corresponding character will be updated in the box with label "Selected characters". Further step is to click on the right arrow button; this allows going to the next pair of dichotomous keys. At any time during this process the list of matched taxa tell us that all these taxa have all the characters in the box with label "Selected characters". The identification finished when the list of taxa under the label "Matched taxa:" will consist of only one taxon and the list of the characters in the box under the label "Selected characters" is the path of specimen identification (Fig. 5).

The left arrow button can be used when the characters were wrongly chosen and it is necessary to go backward to check the previous steps.

Once the specimen is identified, in order to display illustration of the result, it is only needed to click on the button

BK BioKeys - [BioKeys - Key file child window - Hornworts Columbia.bks]

BK $\underline{D}$ atabase Working with polyclave key Working with dichotomous key Options Info Opened database: NewDatabase.bkd

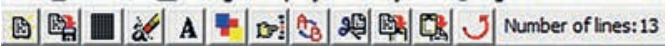

Dichotomous key for Hornworts of Columbia [GENUS], S. Robert Gradstein, Caldasia 40(2):262-270, 2018

1.Thallus usually light green, whole thallus strongly crisped. Thallus differentiated into a midrib and unistratose wings. On branches,

1.Thallus light green to dark green, whole thallus not strongly crisped. Thallus thickened to near the margins, not differentiated into 1

-2 .Thallus deep green to blackish-green, elongate, not forming rosettes, margins finely ruffled and \pm colorless or subentire and gre

-2 .Thallus light green to deep green, usually forming rosettes, margins plane to crispate, green, not finely ruffled. Spores yellow, b1

-3. Thallus with internal cavities. Dorsal thallus surface reticulate due to cavities inside the thallus. Spores brown or black: ANTH

-3. Thallus solid, without cavities. Dorsal thallus surface not reticulate. Spores yellow to brownish

-4 . Thallus margins entire, dorsal thallus surface finely roughened by projecting epidermis cells. Thallus when fresh with long $t$

--4 . Thallus margins entire or dissected, dorsal thallus surface not roughened by projecting epidermis cells. Thallus when fresh

-5 .Sporophytes lying nearly horizontally on the thallus, ellipsoid, less than $5 \mathrm{~mm}$ long. Mainly lowlands: NOTOTHYLAS

-5 .Sporophytes erect, more than $5 \mathrm{~mm}$ long, narrowly cylindrical. Montane, up to the páramo

-6. Outer spore surface vermiculate and with one or more rounded depressions: PHAEOMEGACEROS

-6.Outer spore surface with spines or papillae, not vermiculate, without rounded depressions: PHAEOCEROS

Figure 3 Child window with created dichotomous key

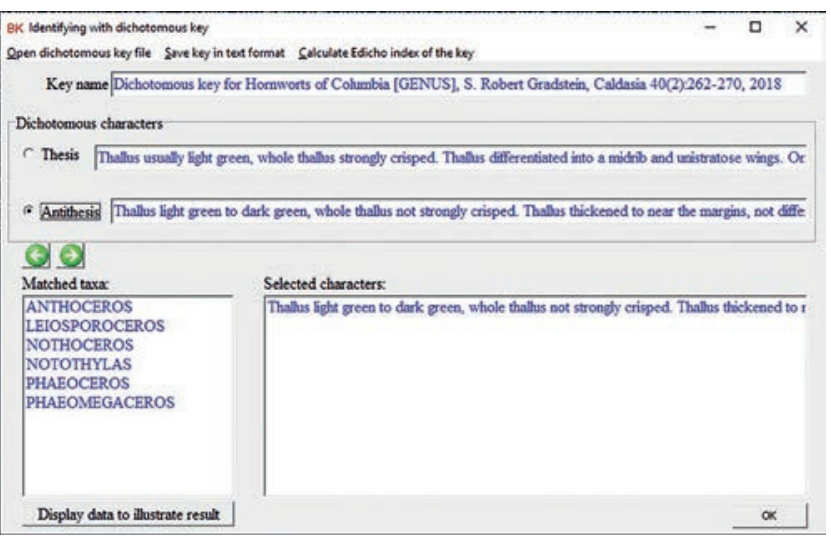

Figure 4 Dialog box for identifying specimen

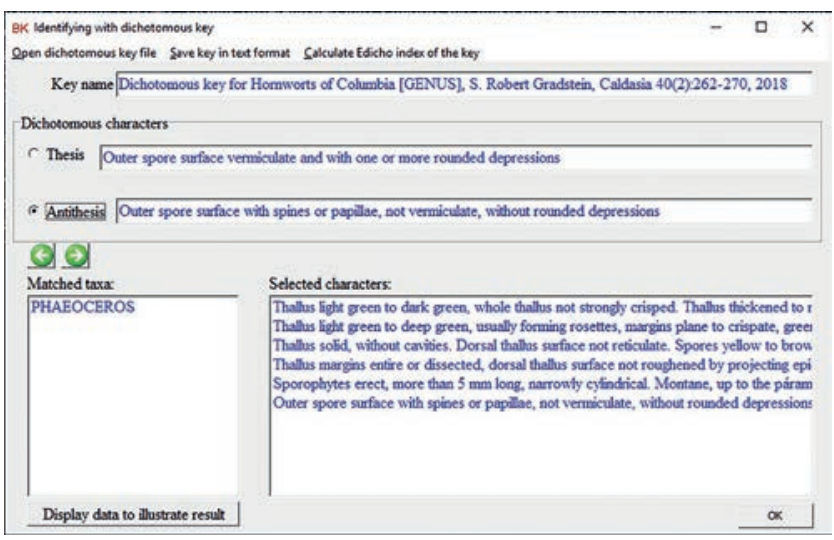

Figure 5 The final result of the specimen identification 


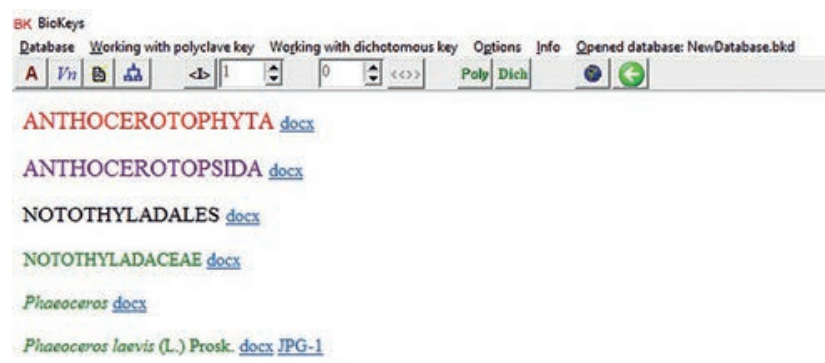

Figure 6 The display of the identification result

"Display data to illustrate the result". The BIOKEYS then will be based on the key word in the rectangular bracket in key name search for all the matched records in the database and display them in the form of a webpage (Fig. 6).

\section{Calculation of $E_{\text {dicho }}$ index for evaluating dichotomous keyich BIOKEYS}

Clicking on the submenu "Calculate $\mathrm{E}_{\text {dicho }}$ index" under the menu "Working with dichotomous key" will cause the software to display the open dialog box for choosing a file of dichotomous key. The dichotomous key in the chosen file will be analyzed and its $\mathrm{E}_{\text {dicho }}$ index will be calculated. The result will be shown in a message box (Fig. 7).

The BIOKEYS software is now fully functional for working with polyclave and dichotomous keys. Working with BIOKEYS taxonomists can easily manage large amount of information that is especially valuable when large groups are in hand. It is now only important to create the pairs of dichotomous characters and the list of taxa that have each of this character. Once a large amount of pairs of dichotomous characters was created, it is possible to choose the best pair of dichotomous characters (also in

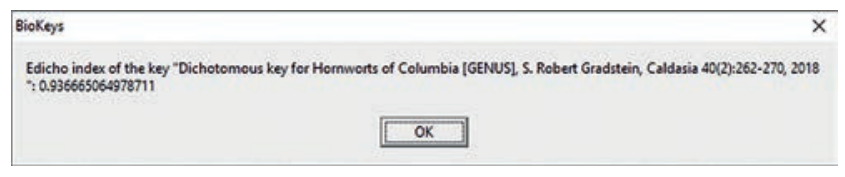

Figure 7 Message box with the calculated $\mathrm{E}_{\text {dicho }}$ index value of the dichotomous key

the evolutionary and phylogenetic meaning) for the key to be created. The BIOKEYS software enables also easy calculation of $\mathrm{E}_{\text {dicho }}$ index that shows the performance of the key (Nguyen et al. 2017).

\section{ACKNOWLEDGEMENTS}

The work is supported by the project NCVCC09.08/19-19 and the project UQĐTCB.05/19-20 funded by Vietnam Academy of Science and Technology.

\section{LITERATURE CITED}

Gradstein, S.R. 2018. Key to hornworts (Anthocerotophyta) of Colombia. Caldasia 40(2):262-270.

Nguyen, V.S. 2015. BIOKEYS - an integrated system for working with database and polyclave identification keys of various taxonomic levels. Vietnam Journal of Science and Technology 53 (2): 127-138.

Nguyen, V.S., M. Wiemers \& J. Settele 2017. Proposal for an index to evaluate dichotomous keys. ZooKeys 685: 83-89.

Pielou, E.C. 1966. The measurement of diversity in different types of biological collections. Journal of Theoretical Biology 13:131-144. 